\title{
SERANGGA HAMA TERKINI YANG MENYERANG TANAMAN SENGON (Falcataria moluccana (Miq.) Berneby \& J.W Grimes) DAN JABON (Neolamarckia cadamba (Roxb.) Bosser)
}

\author{
Illa Anggraeni ${ }^{1)}$, Neo Endra Lelana ${ }^{1)}$, Agus Ismanto ${ }^{2)^{*}}$ \\ ${ }^{1)}$ Pusat Penelitian dan Pengembangan Hutan \\ ${ }^{2)}$ Pusat Penelitian dan Pengembangan Hasil Hutan \\ Jl. Gunungbatu No. 5, Bogor 16610 \\ *e-mail: ismanto_agus@yahoo.com
}

\begin{abstract}
The Latest Insect Pests which Attacks Sengon (Falcataria moluccana(Miq.) Berneby \& J.W Grimes) and Jabon Trees (Neolamarckia cadamba(Roxb.) Bosser)
\end{abstract}

\begin{abstract}
The current study of pest insect infestation on sengon (Falcataria moluccana(Miq.) Berneby \& J.W Grimes) and jabon (Neolamarckia cadamba (Roxb.) Bosser) plants has been carried out. The aimed of the study was to identify the latest status of the pests that infested sengon and Jabon plants. The research method used were field survey and observation in the laboratory. The survey was carried out in plantations owned by the Unit II Perhutani Unit in East Java as well as the small scale forests in the Kediri (East Java), Ciamis and Garut (West Java) areas. Observations in the laboratory were conducted at the Pest Laboratory of the Center for Forest Research and Development, Bogor. The results showed that pests that infested sengon and jabon plants were unknown name of sengon shoot borer, Echinothrips sp. (Tripidae; Thysanoptera), horn beetle Oryctes rhinoceros (Scarabaeidae; Coleoptera), wild silkworm Attacus atlas (Saturniidae; Lepidoptera), leaf-sucking pests Lawana sp./ Sanurus sp. (Flatidae; Homoptera).
\end{abstract}

Keywords: pest insect, sengon plant, jabon plant, the latest.

\begin{abstract}
ABSTRAK
Telah dilakukan penelitian tentang serangga hama terkini yang menyerang tanaman sengon (Falcataria moluccana) dan jabon (Neolamarckia cadamba) di hutan tanaman. Tujuan penelitian ini adalah untuk menginventarisir jenis-jenis hama yang menyerang tanaman sengon dan jabon saat kini. Metode penelitian yang digunakan adalah metode survei dan pengamatan di laboratorium. Survei dilakukan di hutan tanaman milik Perum Perhutani maupun hutan milik rakyat di daerah Kediri, Ciamis dan Garut. Pengamatan di laboratorium dilakukan di Laboratorium Hama Pusat Penelitian dan Pengembangan Hutan, Bogor. Hasil penelitian menunjukkan bahwa hama yang menyerang tanaman sengon dan jabon adalah hama penggerek pucuk sengon (Pyralidae; Lepidoptera), hama Echinothrips sp. (Tripidae; Thysanoptera), kumbang tanduk Oryctes rhinoceros (Scarabaeidae; Coleoptera), ulat sutera liar Attacus atlas(Saturniidae; Lepidoptera), hama pengisap daun Lawana sp./ Sanurus sp. (Flatidae; Homoptera).
\end{abstract}

Kata kunci: serangga hama, tanaman sengon, tanaman jabon, terkini

\section{PENDAHULUAN}

Seiring dengan pesatnya pertambahan penduduk dan pesatnya perkembangan bidang perkayuan di Indonesia, maka kebutuhan lahan dan konsumsi kayu semakin meningkat, tekanan terhadap sumber hutan pun cenderung semakin meningkat. Sementara itu hutan alam sudah tidak mampu lagi untuk memenuhi pasokan kayu, karena adanya deforestasi dan degradasi hutan yang merupakan penyebab utama kerusakan sumber daya hutan di Indonesia. Untuk memenuhi kebutuhan kayu perlu dicari alternatif pengganti yang diharapkan dapat disubstitusi dari kayu hasil hutan tanaman (Hutan Tanaman Industri/ HTI dan Hutan Tanaman Rakyat/ HTR), perkebunan dan hutan rakyat.Tanaman yang sekarang banyak diusahakan dan 
dikembangkan di kawasan hutan tanaman, perkebunan maupun di kebun-kebun milik rakyat (hutan rakyat) di pulau Jawa dan di luar pulau Jawa adalah sengon (Falcataria moluccana) dan jabon (Neolamarckia cadamba). Hal ini karena sengon dan jabon mempunyai beberapa kelebihan dan keunggulan dibandingkan dengan tanaman hutan yang lain. Kelebihan sengon dan jabon antara lain ialah pertumbuhannya yang sangat cepat (fast growing species) sehingga dapat dipanen dalam waktu yang relatif singkat, sekitar 5-8 tahun. Kedua tanaman tersebut dapat beradaptasi pada berbagai lingkungan, dan keduanya merupakan tanaman asli Indonesia (Pratiwi, 2003; Krisnawati, Kallio, \& Kanninen, 2011a; Krisnawati, Varis, Kallio dan Kanninen, 2011b).

Kenyataan di lapangan dalam pengembangan hutan tanaman sengon dan jabon dalam skala luas maupun skala terbatas umumnya bersifat monokultur, dalam keadaan yang demikian ekologinya cenderung untuk memacu peningkatan populasi hama seperti yang terjadi pada ekosistem perkebunan dan pertanian. Ekosistem monokultur dapat lebih rentan terhadap kerusakan oleh hama karena tidak adanya keanekaragamanjenis tanaman dan adanya perubahan cuaca yang disebabkan oleh manusia, serta melimpahnya dan terkonsentrasinya sumber pakan bagi hama dalam satu hamparan. Beberapa jenis hama sengon yang telah diketahui sering menyerang antara lain Eurema blanda dan E. Hecabe (hama daun); Amatissa sp., Claniasp., Cryptothelea sp. Dan Pteroma plagiophleps (ulat kantong); Indarbella acutistriata (penggerek cabang dan batang); Lepidiota stigma (uret/embug); Xystrocera festiva dan X. Globosa (penggerek batang); kutu daun dan rayap. Beberapa jenis hama yang sudah diketahui menyerang tanaman jabon antara lain Arthroschista hilaralis, Coptotermes sp., Cosmoleptrus sumatranus, Daphnis hypothous, Valanga nigricornis dan Zeuzera sp.

Penelitian dengan metode survei tentang serangga hama terkini dilaksanakan di hutan sengon dan jabon milik masyarakat serta milik Perusahaan Hutan Negara (Perum Perhutani). Hasil survey telah ditemukan serangga-serangga yang baru kali ini menyerang tanaman hutan sengon dan jabon yaitu hama trips yang menyerang bibit sengon di persemaian dan hama penggerek pucuk menyerang sengon muda di lapangan; Sedangkan serangga yang menyerang tanaman jabon di lapangan adalah kumbang tanduk, hama pengisap daun jabon dan ulat sutera liar. Untuk dapat mengatasi gangguan dari berbagai macam serangga hama terkini tersebut di lingkungan hutan tanaman sengon dan jabon sangat diperlukan mengenal jenis hama dengan mempelajari gejala dan akibat yang ditimbulkannya, ekobiologi dari hama, serta cara penyerangan.

\section{BAHAN DAN METODE}

\section{Bahan dan Alat}

Bahan dan alat yang digunakan dalam penelitian antara lain tegakan sengon umur 1 tahun dan bibitsengon umur 1 bulan, jabon umur 2-5 tahun, madu, kapur anti semut, alkohol 70\%, akuades,larutan hoyer, kertas tisu,kapas, jaring serangga, kotak serangga, botol spesimen, cawan petri, gelas obyekkaca penutup, kuas halus, pipet, pinset, jarum ose, sarung tangan, kertas/karton putih, loupe, kamera digital dan kamera mikroskop.

\section{Metode}

Pengamatan dilakukan di lapangan dan di laboratorium yang meliputi,

- Pengamati gejala serangan hama pada tanaman sengon dan jabon secara visual.

- Penangkapan imago sutera liar dan pengambilan pupanya, imago dikumpulkan dalam kotak serangga. Imago dipelihara dengan memberi madu pada kapas, diamati kapan bertelur, kapan telur menetas bentuk serta warna telur maupun larva. Di setiap kotak serangga sekelilingnya diberi kapur anti semut.

- Pengambilan hama penggerek pucuk sengon, kumbang tanduk jabon dan hama pengisap daun jabon untuk keperluan identifikasi di laboratorium. 
- Pengambilan hama trips yang berukuran kecil dilakukan dengan menggunakan kuas halus atau mengetuk-ngetuk bagian daun bibit sengon di atas kertas/karton putih trips kemudian dimasukkan ke dalam botol spesimen.

- Pembuatan preparat menggunakan bentuk imago trips. Imago dimasukkan ke dalam alkohol $70 \%$, kemudian sayap direntangkan serta antenanya diluruskan. Bagian ventral tubuh berada di sebelah atas pada kaca obyek. Larutan Hoyer diteteskan pada kaca penutup, kemudian imago yang telah diatur posisinya pada kaca obyek tersebut segera ditutup menggunakan kaca penutup yang telah diberi larutan Hoyer. Setelah kaca obyek menempel pada larutan Hoyer. Preparat dikeringkan pada hot plate bersuhu $40^{\circ} \mathrm{C}$ selama 2 hari. Kemudian bagian tepi kaca penutup ditutup dengan menggunakan cat kuku yang berwarna transparan.

- Pemotretan dilakukan secara makroskopis dan mikroskopis terhadap hama yang diperoleh.

\section{HASIL DAN PEMBAHASAN}

Hasil identifikasi dilaboratorium menunjukkan bahwa hama penggerek pucuk sengon belum teridentifikasi, hama ini secara morfologi larvanya mirip dengan Hypsipyla sp. (hama penggerek pucuk mahoni). Hama trips yang menyerang bibit sengon teridentifikasi Echinothrip sp. Hama ulat sutera liar yang menyerang jabon teridentifikasi Attacus atlas, kumbang tanduk yang menyerang jabon adalah Oryctes rhinoceros dan hama pengisap daun adalah Lawana sp. yang sekarang disebut Sanurus sp. (wereng lilin/sikada putih/wereng putih/wereng pucuk).

\section{Hama Penggerek Pucuk Sengon (Lepidoptera).}

Hama penggerek pucuk sengon ini belum teridentifikasi tetapi dari hasil pengamatan menunjukkan hama ini mirip dengan hama penggerek pucuk mahoni, tetapi informasi dari pustaka belum ada yang mencatat bahwa hama penggerek pucuk mahoni juga menjadi hama penggerek pucuk sengon. Hama penggerek sengon ini masuk ke dalam kelompok Lepidoptera. Kelompok Lepidoptera terdiri dari ngengat dan kupukupu, salah satu ordo yang paling tersebar, paling dikenal dan paling sukses dalam hidupnya. Tubuh dan sayap Lepidoptera ditutupi bulu dan sisik, imago mempunya proboscis. Ngengat penggerek pucuk sengon aktif terbang pada malam hari untuk melakukan perkawinan dan bertelur. Dalam kehidupannya hama penggerek pucuk sengon mengalami empat tahap perkembangan atau mengalami metamorfosa sempurna yaitu telur-larva-pupa-imago. Imago berupa ngengat, imago betina meletakkan telur di pucuk pohon atau pada daun dan ranting muda. Telur menetas menjadi larva instar satu yang langsung mencari pucuk serta menggereknya ke arah bawah, di dalam lubang gerek inilah terjadi peralihan dari instar satu ke instar dua dan seterusnya hingga terbentuk pupa pada dasar lubang gerek. Pada umumnya setiap lubang gerek berisi hanya satu ekor larva.

Serangan penggerek pucuk dapat dikenali dengan adanya daun-daun muda dan pucuk daun sengon pada bagian tersebut mengalami nekrosis yang layu, mati dan kering. Hama penggerek pucuk sengon sama denganserangan hama-hama penggerek pucuk yang lain yaitu hama membuat lubang gerek pada pucuk tanaman sengon muda, pada permukaan lubang gerek yang masih baru terdapat kotoran yang bercampur dengan jaringan tanaman/serbuk gerek yang bercampur dengan lendir berwarna coklat. Stadium larva ini terus menggerek dan membuat saluran menuju empulur (jaringan silem) terutama bagian yang masih lunak dari batang pohon. Untuk mengetahui serangan dalam batang ada tidaknya larva, maka batang dibelah dan tampaklah terowongan/lubang gerek yang cukup panjang dengan berisi larva atau sudah bentuk pupa. Akibat serangan hama penggerek pucuk sengon dapat mempengaruhi distribusi hara dan air serta menghambat pertumbuhan tanaman, bagian pucuk tanaman menjadi kering bahkan pada 
serangan yang lebih lanjut tanaman sengon muda menjadi mati (Gambar 1).
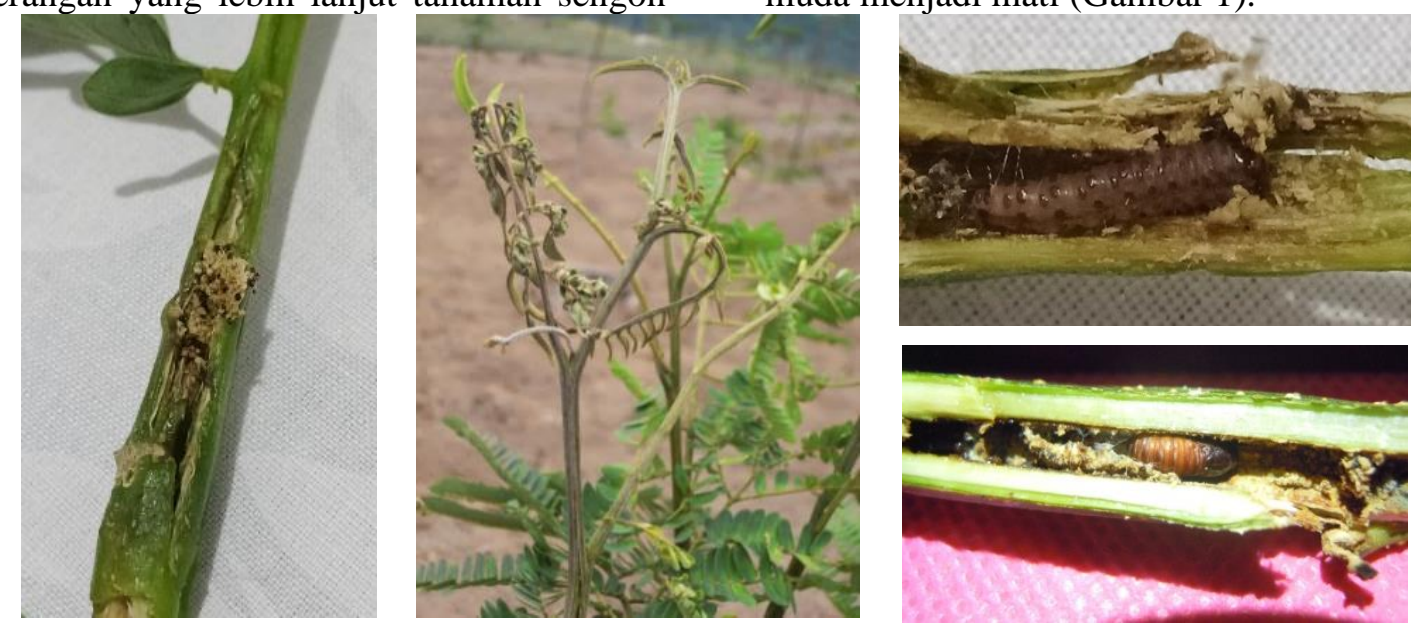

Gambar 1. Penggerek Pucuk Sengon, Gejala dan Akibat Serangan, Bentuk Larva dan Bentuk Pupa

\section{Hama Trips (Tysanoptera)}

Informasi tentang serangan hama trips pada tanaman pertanian (tanaman sayuran hingga tanaman hias) sudah banyak dipublikasikan, tetapi informasi hama trips yang menyerang tanaman hutan relatif belum ada. Oleh karena itu informasi ini sangat penting, agar para pengelola tanaman hutan mewaspadainya.

Hasil pengamatan di lapangan dan laboratorium trips yang menyerang bibit sengon adalah Echinothrips sp. Echinothrips memiliki klasifikasi Kingdom: Animalia; Filum: Arthopoda; Kelas : Insecta; Ordo :Tysanoptera; Famili: Tripidae; Genus: Echinothrips; Spesies : Echinothrips sp. Hama trips bersifat fitofag, mikofag, atau predator yang memiliki kisaran habitat luas, yaitu di daerah tropik, subtropik, dan daerah temperate. Trips mempunyai ukuran tubuh yang sangat kecil $(0,5 \mathrm{~mm}-2 \mathrm{~mm})$, bertubuh ramping, pada kepalanya terdapat sepasang antena yang pendek beruas-ruas. Imago trips mempunyai dua pasang sayap berumbai. Bersayap rumbai inilah yang merupakan salah satu ciri khas morfologis yang paling penting untuk trips. Oleh karena itu trips termasuk ke dalam ordo Thysanoptera (thysanos = rumbai; pteron = sayap) (Borror,Triplehorn \& Johnson, 1992). Spesies trips yang tersebar di seluruh dunia berjumlah \pm 8.000 spesies dan lebih dari 5.500 spesies telah dideskripsikan (Morse \& Hoddle, 2006). Daerah penyebaran trips di Indonesia pada tanaman pertanian antara lain di Jawa Timur, Bali, Nusa Tenggara Barat, Nusa Tenggara Timur dan Sulawesi, sedangkan pada tanaman kehutanan baru diketahui di Jawa Barat.

Hasil pengamatan di lapangan dan laboratorium imago trips mempunyai warna tubuh hitam, larva trips berwarna putih bening, kemudian berubah menjadi agak kecoklat-coklatan (Gambar 2). Trips dapat berkembangbiak secara partenogenesis (tidak kawin) maupun melalui pembuahan (kawin), trips betina dihasilkan dari telur yang didahului proses pembuahan, sementara trips jantan tidak dihasilkan dari proses pembuahan. Hama trips mengalami metamorfosis peralihan yaitu antara holometabola dan paurometabola dengan dua atau tiga instar pradewasa yang tidak aktif bergerak. Siklus hidup diawali oleh telur yang berukuran sangat kecil (tidak kasat mata), setelah stadia telur dilanjutkan dengan stadia larva untuk hama trips ini ada 2 tahapan instar larva yang aktif makan, kemudian 2 atau 3 instar serangga yang tidak aktif makan (prapupa dan 1 atau 2 instar berpupa), dan terakhir imago (dewasa). Prapupa merupakan tahap setelah trips mengalami ganti kulit dari instar kedua, pada tahapan ini mulai terbentuk embelan sayap dan gerak trips mulai tidak aktif. Pada fase pupa embelan sayap akan semakin terbentuk sempurna, tetapi bulu sayap yang berupa rumbai-rumbai belum terbentuk dan warna trips menjadi cokelat muda. Imago trips muncul setelah pupa dan ditandai 
dengan berkembangnya organ secara sempurna (Gambar 3) (Mound dan Kibby, 1998).

Serangga ini mempunyai alat mulut yang bertipe pencucuk-penghisap, meskipun lebih tepat disebut sebagai pemarut. Trips akan mengisap cairan tumbuhan yang keluar dari jaringan yang terlebih dahulu dilukai dengan mulutnya. Serangan hama trips dapat berdampak pada kerusakan secara langsung dan kerusakan secara tidak langsung. Dampak kerusakan secara langsung adalah diawali dengan trips yang hinggap di daun muda/pucuk daun (permukaan daun bagian bawah) kemudian menusuk dan menghisap cairan daun, sehingga menimbulkan bercakbercak berwarna putih seperti perak, bercak putih seperti perak inilah ciri khas serangan trips pada permukaan daun. Timbulnya bercak putih keperak-perakan ini akibat dari jaringan-jaringan sel daun yang telah dihisap cairannya menjadi kosong dan kemudian masuklah udara, perpaduan udara dengan unsur besi penyusun utama klorofil daun menimbulkan warna keperak-perakan dan menyebabkan gangguan fisiologi pada daun. Apabila bercak-bercak tersebut saling menyatu maka daun akan memutih keseluruhannya seperti perak yang kemudian menjadi kecoklat-coklatan. Pada serangan lebih lanjut (serangan berat) daun, pucuk serta tunas pada bagian tepinya mengkerut karena cairannya dihisap, mengeriting dan menggulung (malformasi), akhirnya daun rontok, pucuk mati. Selain bercak-bercak putih pada daun, terdapat kotoran hama berbentuk seperti tetesan hitam yang dapat menutupi permukaan daun. Trips juga menghasilkan cairan madu yang dapat mengundang fungi embun jelaga tumbuh pada permukaan daun. Kerusakan secara tidak langsung yang ditimbulkan oleh hama trips adalah serangga tersebut menjadi vektor penyakit yang disebabkan oleh virus, sehingga tanaman inang menjadi menguning dan mati. Hama trips ini mengakibatkan turunnya jumlah produktivitas bibit sengon, bahkan dapat mengakibatkan kematian. Serangan trips umumnya terjadi pada musim kemarau.

\section{Kumbang tanduk/ Oryctes rhinoceros (Coleoptera).}

Hasil identifikasi di laboratorium kumbang tanduk yang menyerang jabon adalah jenis $O$. rhinoceros. Kumbang tanduk termasuk Kingdom: Animalia; Filum: Arthropoda; Kelas: Insecta; Ordo: Coleoptera; Famili: Scrabaeidae; Genus: Oryctes; Species: O. rhinoceros (Borror et al.,1992)
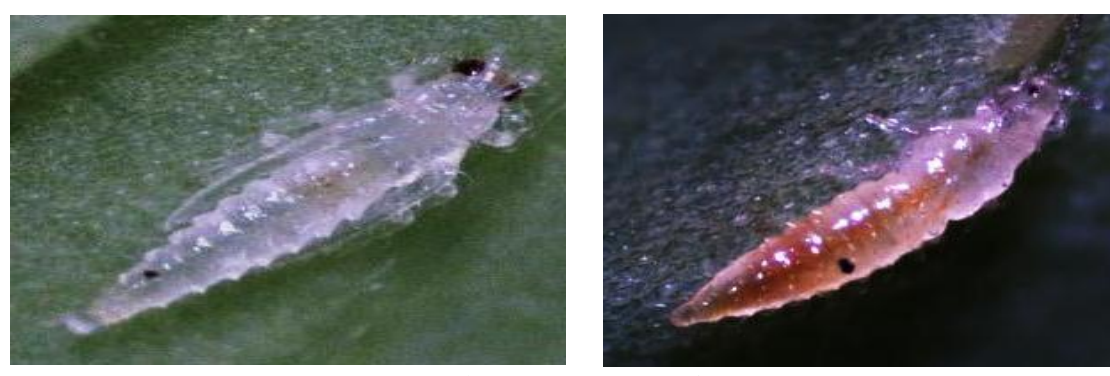

Gambar 2. Larva Trips
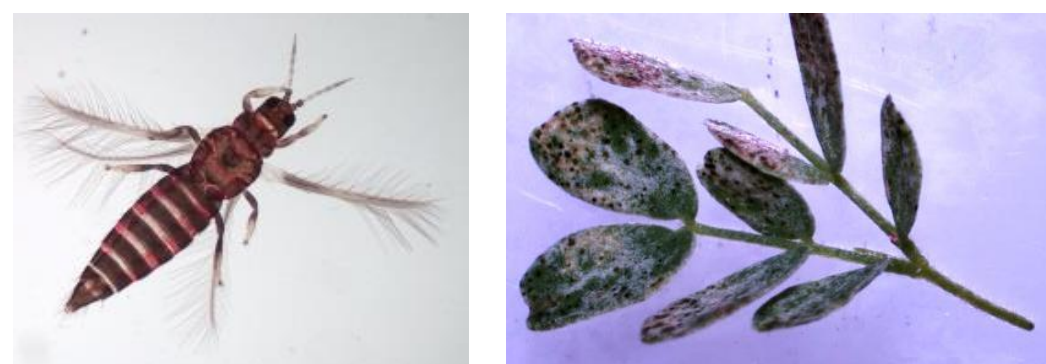

Gambar 3. Imago Trips dan Akibat Serangan pada Daun Sengon 
Kumbang tanduk merupakan hama utama dari kelapa sawit atau sering menyerang kelompok Palmae, baru kali inilah hama kumbang tanduk menyerang tanaman hutan yaitu jabon. Hama ini merupakan serangga yang mengalami metamorfosa sempurna (holometabola) dengan empat tahap yang terdiri dari telurlarva-pupa-imago, pada tahapan dewasa berbentuk kumbang yang berukuran $\pm 5 \mathrm{~cm}$. Menurut para ahli serangga, lama proses metamorfosis pada kumbang tanduk atau bervariasi tergantung spesies dan lingkungan. Siklus hidup $O$. rhinoceros berlangsung cukup lama (3,5-8 bulan). Hasil pengamatan di lapangan dan laboratorium, kumbang dewasa berwarna coklat sampai hitam mengkilat dan tubuh bagian bawah berwarna coklat kemerahan, cembung pada bagian punggung dan bersisi lurus. Kepala kumbang jantan mempunyai tanduk satu yang lebih panjang dari kumbang betina dan agak melengkung, sedangkan kumbang betina mempunyai tanduk hanya berupa tonjolan dan disekitar ekor berambut lebat (Gambar 4). Ukuran tanduk merupakan indikator kesehatan fisik kumbang jantan. Tanduk pada Kumbang jantan berfungsi untuk bertarungan memperebutkan makanan dan daerah kekuasaan untuk menarik perhatian kumbang betina. Tanduk juga dapat digunakan untuk menggali tanah dan mengubur diri di dalam tanah, bersembunyi dari bahaya. Kumbang tanduk memiliki sayap dan dapat digunakan untuk terbang. Kumbang aktif pada malam hari untuk melakukan melakukan perkawinan, dimana perkawinan kumbang tanduk biasanya pada daerah yang tinggi yaitu di pohon. Pada saat kumbang betina akan bertelur kumbang turun mencari tumpukan sampah, limbah tanaman atau jerami yang sudah membusuk, batang pohon lapuk, bahkan pada kotoran hewan. Telur berbentuk lonjong kemudian membulat berwarna putih, beberapa waktu kemudian telur menetas menjadi larva berwarna putih kemudian berwarna putih kekuningan dengan kepala coklat kemerahmerahan, tubuh bagian belakang larva lebih besar dibandingkan dengan tubuh bagian depan. Larva kumbang tanduk juga disebut uret. Permukaan tubuh larva ditumbuhi bulu-bulu pendek dan pada bagian ekor bulu-bulu tersebut tumbuh lebih rapat. Stadium larva terdiri dari tiga instar yaitu instar I, instar II dan instar III. Pada saat instar III berakhir maka membentuk pupa berwarna coklat. Pada stadium pupa sudah tampak bagian kepala, sayap dan tungkai. Pupa berada dalam kokon yang terbuat dari tanah dan daun-daunan. Pada saat pupa berubah menjadi kumbang muda, kumbang muda tersebut tetap berada dalam kokon beberapa hari ( \pm 2 minggu), kemudian imago keluar dari kokon pada malam hari, selanjutnya siklus hidup kembali berlangsung (Suhadirman, 1996; Susanto, 2005; Susanto, 2012).

Kumbang menyerang batang jabon diawali dengan menggerek bagian kulit batang hingga mengelupas dan terbentuk kubah yang cukup lebar pada batang, kumbang terus menggerek hingga terbentuk lobang gerek yang cukup dalam sampai pada kayu gubal. Stadia yang membahayakan adalah pada stadia dewasa. Dalam satu tanaman ditemukan antara 4 sampai 6 kumbang, luka akibat gerekan kumbang pada batang, dapat menimbulkan terjadinya serangan sekunder yaitu timbulnya penyakit yang disebabkan fungi patogen, sehingga batang makin cepat membusuk, seperti terlihat pada Gambar 4.
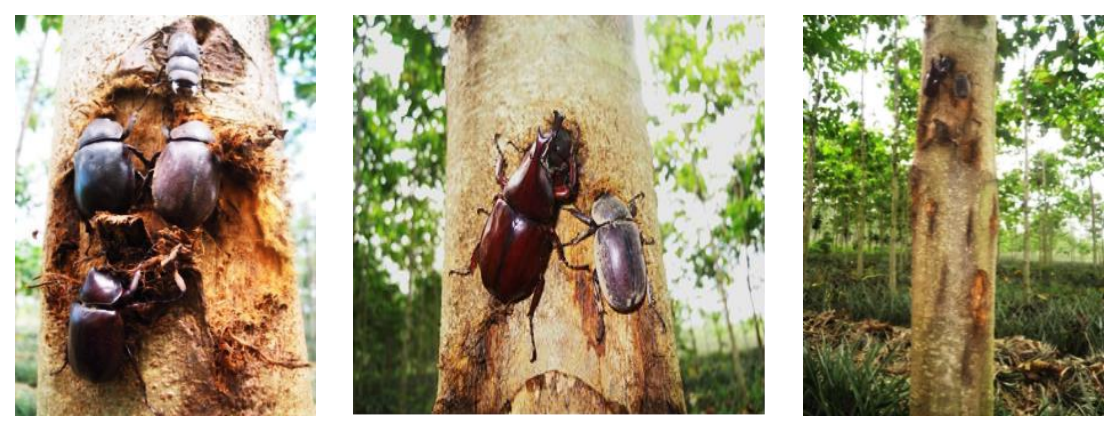
Gambar 4. Kumbang Tanduk dan Akibat Serangannya pada Jabon
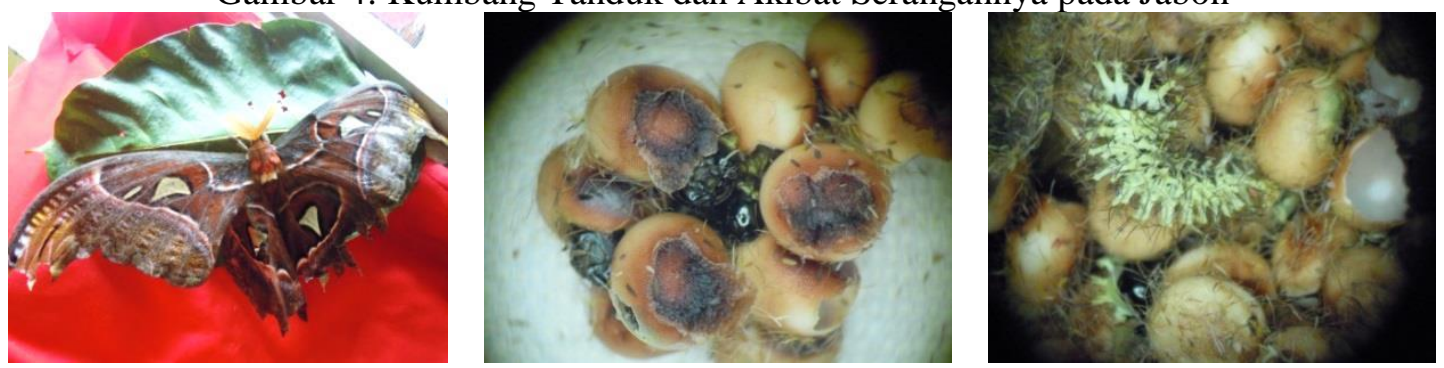

Gambar 5. Imago, Telur, Larva Instar Pertama dari A. atlas

\section{Ulat Sutera liar/ Attacus atlas (Lepidoptera)}

Ulat sutera liar (Attacus atlas) adalah serangga yang masuk ke dalam Ordo Lepidoptera, serangga ini merupakan salah satu serangga asli Indonesia. Serangga ini termasuk hewan polivoltin yaitu memiliki lebih dari tiga generasi per tahun artinya hewan ini dapat hidup sepanjang tahun selain itu serangga ini bersifat polifagus. Menurut Peigler (1989) bahwa ulat sutera liar dapat mengkonsumsi 90 golongan tumbuhan dari 48 famili. Dari berbagai informasi yang dihimpun bahwa ulat sutera liar di Indonesia dapat memakan daun sirsak, jeruk, dadap, alpukat, teh, cengkeh, mangga dan berbagai pohon berkayu keras lainnya. Klasifikasi A. atlas sebagai berikut: Kingdom: Animalia; Filum: Arthopoda; Kelas: Insekta; Ordo: Lepidoptera; Famili: Saturniidae; Genus: Attacus (Linnaeus); Spesies: Attacus atlas (Linnaeus) (Peigler, 1989).

Hasil pemeliharan dan pengamatan di laboratorium menunjukkan bahwa $A$. atlas memiliki tahapan metamorfosa sempurna (holometabola) yang terdiri dari telur, larva (5 instar), pupa dan tahapan dewasa/imago. Pada tahapan dewasa bentuknya kupu-kupu, tetapi sebenarnya $A$. atlas tidak termasuk dalam kelompok kupu-kupu (butterfly) melainkan termasuk ngengat (moth: kupukupu malam). Ngengat ulat sutera merupakan serangga yang cenderung aktif pada malam hari. Imago A. atlas disebut ngengat sutera raksasa, si rama-rama atau kupu gajah (rentang sayap dari kupu-kupu $A$. atlas $\pm 20 \mathrm{~cm}$ ) dengan warna dominan coklat, di tengah sayap terdapat corak putih sehingga disebut atlas (Gambar 5), sedangkan larvanya di beberapa daerah disebut hileud haji,hileud orok, ulat badori, ulat gajah, ulat jedhug dan ulat keket.

Kehidupan A. atlas dimulai dari pendekatan ngengat jantan terhadap ngengat betina karena ngengat betina mengeluarkan feromon. Setelah terjadi kopulasi ngengat betina bertelur, telur $A$. atlas terdiri dari dua jenis, telur yang dihasilkan dari perkawinan jantan dan betina (telur fertil) dan telur yang bukan hasil perkawinan (telur steril) yang tidak bisa menetas. Telur fertil dan telur steril bila di lapangan diletakkan di atas permukaan daun jabon secara berkelompok maupun terpisah-pisah. Sedangkan telur yang diamati adalah telur hasil dari perkawinan yang dipelihara di laboratorium dalam kotak serangga. Telur diletakkan secara berkelompok atau terpisah pada permukaan dasar kotak serangga dan dinding kasa. Telur yang berkelompok sepertinya satu sama lain melekat serta diselubungi oleh benang-benang sutera, telur berbentuk agak bulat, berwarna coklat muda, di satu bagian ujung telur berwarna coklat tua pekat (Gambar 5). Telur menetas hingga larva mengganti kulit pertama (instar 1) dan keluarlah larva/ulat dengan kepala warna hitam mengkilat, dengan badan larva berwarna hitam dan tubuhnya ditumbuhi bulu berwarna kuning kehijau-hijauan pucat tanpa serbuk putih (Gambar 5). Larva $A$. atlas melalui 6 tahapan instar, dimana pada setiap instar, ciri, ukuran dan tingkah laku larva berbeda sesuai dengan pertumbuhan dan perkembangan larva. Selama metamorfosa, stadium larva adalah satusatunya masaulat makan, fase ini merupakan masa yang sangat penting. Pergantian masa instar pertama ke instar kedua, instar kedua ke instar ketiga sampai instar ke enam, ditandai dengan beberapa kali pergantian kulit (molting) pada saat-saat tertentu karena 
ukuran larva yang bertambah besar. Larva instar 2 dan 3 sedikit berbeda dengan larva instar 1, larva mengalami perubahan yaitu bagian kepala yang tadinya berwarna hitam pekat mengkilat menjadi hitam kecoklatcoklatan, tubuhnya mulai ditutupi oleh serbuk putih. Larva instar 4 dan 5 kepalanya berwarna hijau, pada bagian abdomen terdapat duri-duri sebagai tonjolan-tonjolan dari otot (skoli) (Gambar 6) (Peigler, 1989). Pada saat instar keenam terbentuklah kokon, kokon terbentuk dari cairan sutera yang dikeluarkan larva, besarnya kokon disesuaikan dengan ukuran tubuh larva. Cairan sutera tersebut juga untuk melekatkan kokon pada ranting dan daun tanaman inang (Gambar 6). Larva terus mengeluarkan cairan sampai kokon terbentuk dengan sempurna. Pada stadium ini terjadi pembentukan organ-organ imago yang terdiri atas sayap, kaki, kepala dan struktur reproduksi (organogenesis). Posisi larva didalam kokon kepalanya berada dibagian atas, posisi ini akan memudahkan dan menguntungkan ketika imago keluar dari kokon. Setelah masa pupasi berakhir, imago muncul dari dalam kokon dan biasanya terjadi pada siang hari. Hasil pengamatan di laboratorium (rearing), lama periode tiap fase hidup $A$. atlas masa inkubasi telur $A$. atlas 10 hari, lama periode larva 30 hari, lama periode pupa adalah 20 hari, lama periode imago betina dan jantan masing-masing adalah 2-7 hari. Total waktu yang diperlukan A. atlas untuk menyelesaikan sekali daur hidupnya, mulai dari telur sampai imago bertelur lagi memerlukan waktu 60 hari
Ulat sutera liar menyerang daun jabon terutama daun muda karena sebagai pakannya. Ulat memakan daun dimulai pada bagian pinggir, hingga daun habis yang tinggal adalah tulang daunnya. Serangan ulat sutera liar mengakibatkan tanaman mengalami defoliasi (gundul), sehingga pertumbuhan dan perkembangan tanaman terhambat bahkan dapat mengakibatkan mati kering. Ulat sutera liar ini sebenarnya juga merupakan salah satu serangga yang berguna karena dapat menghasilkan benang sutera, benang sutra yang dihasilkan A.atlas memiliki keunggulan seperti warna benang coklat dan lebih mengkilat sehingga mempunyai harga jual yang lebih tinggi. Benang sutera ini digunakan sebagai bahan utama dalam dunia mode karena memiliki nilai eksklusivitas yang tinggi sebagai rancangan adibusana (Situmorang, 1996; Saleh, 2004)

\section{a. Hama pengisap daun/ Lawana sp./ Sanurus sp. (Homoptera)}

Hama pengisap daun Sanurus sp. merupakan hama yang bersifat fitofag, berdasarkan beberapa informasi hama ini menyerang tanaman pertanian, bahkan Lawana candida atau sekarang disebut Sanurus indecora menjadi hama utama pada tanaman jambu mete yang dikenal dengan hama wereng pucuk mete (Kementrian Pertanian, 2012). Sanurus sp. pada tanaman hutan ditemukan menyerang jabon. Klasifikasi Sanurus sp. sebagai berikut, Kingdom: Animalia; Filum: Arthopoda; Kelas: Insekta; Ordo: Homoptera; Famili: Flatidae; Genus: Sanurus; Species: Sanurus sp.
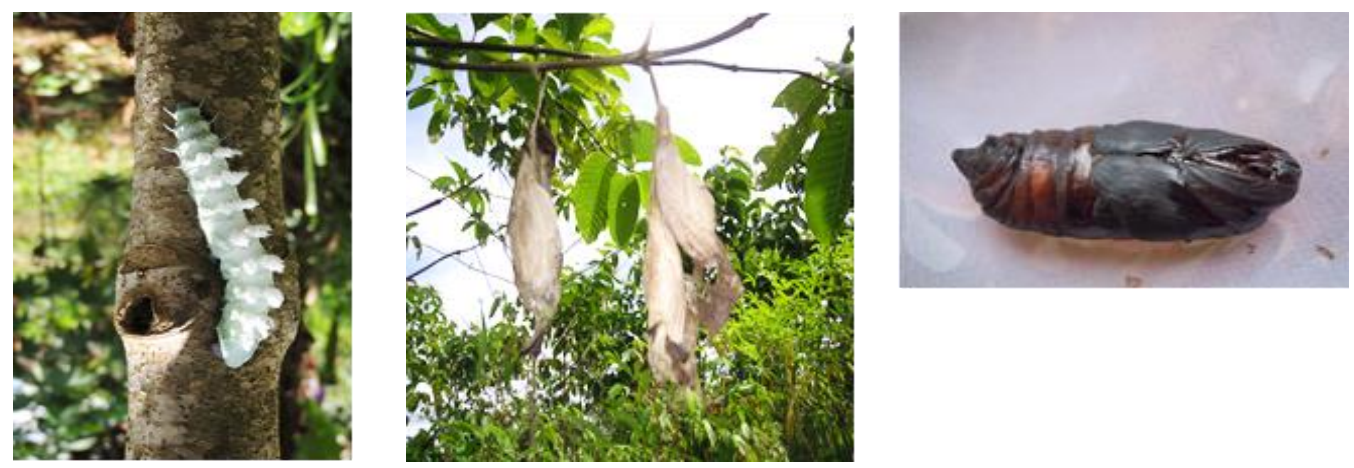

Gambar 6. Larva dan Pupa A. atlas 

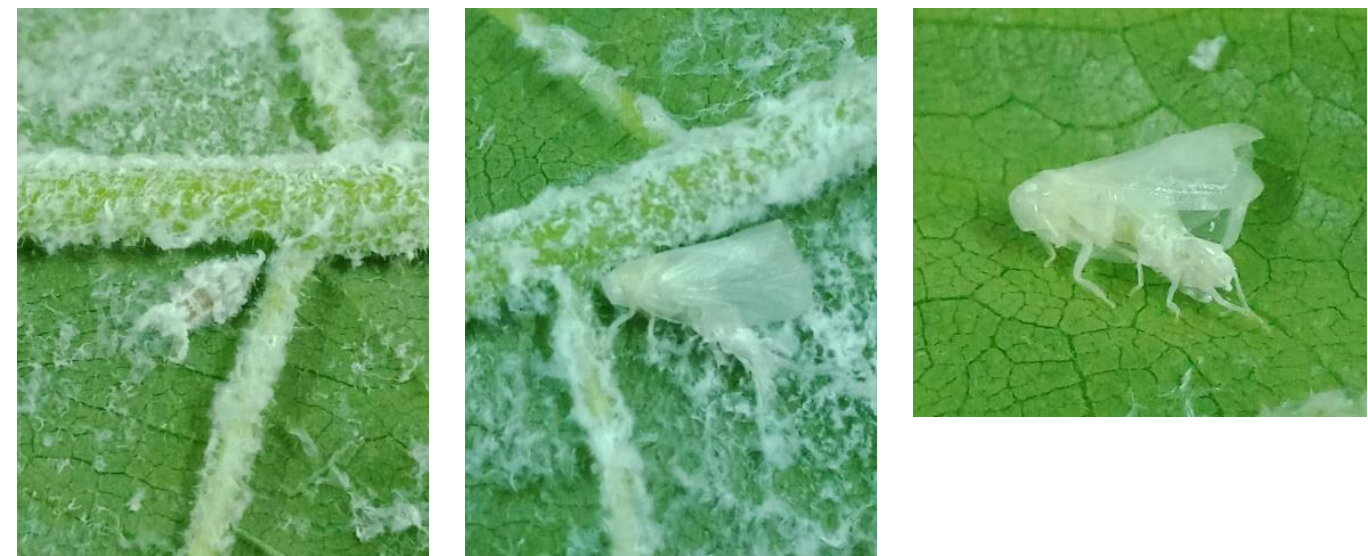

Gambar 7. Lawana sp. pada Jabon

Sanurus sp. mempunyai siklus hidup tidak sempurna (paurometabola) dengan tahapan telur-nimfa-imago (kutu dewasa). Imago betina meletakkan telurnya pada bagian pangkal daun atau di bawah permukaan daun jabon secara berkelompok. Telur-telur tersebut diselimuti oleh lapisan putih mirip tepung. Telur kemudian menetas menjadi nimfa yang juga masih diselimuti lapisan putih, nimfa tidak bergerak bebas tetapi akan meloncat bila terganggu. Setelah stadia nimfa berakhir, muncullah kutu dewasa seperti kupu-kupu (Gambar 7).

Sanurus sp. menyerang daundalam bentuk nimfa dan kutu dewasa dengan cara menusuk dan mengisap cairan daun, terutama daun muda atau pucuk daun. Akibat serangan tersebut menimbulkan titiktitik hitam yang kemudian menonjol, beberapa hasil penelitian menunjukkan bahwa tusukan hama tersebut sampai pada jaringan xylem dan floem, tentunya hal ini menyebabkan terganggunya aliran zat hara. Akibat yang lain, hama ini mengeluarkan/ menghasilkan embun madu sehingga pada permukaan daun tertutup oleh fungi embun jelaga yang mengakibatkan terganggunya proses fotosintesa.

\section{KESIMPULAN}

Berdasarkan survei di hutan sengon dan jabon milik masyarakat serta milik Perusahaan Hutan Negara (Perum Perhutani), di Kediri, Ciamis dan Garut telah ditemukan beberapa hama yang menyerang tanaman sengon dan jabon yaitu hama penggerek pucuk sengon (Pyralidae: Lepidoptera),hama Echinothrips sp. (Tripidae: Thysanoptera), kumbang tanduk Oryctes rhinoceros (Scarabaeidae: Coleoptera), ulat sutera liar Attacus atlas (Saturniidae: Lepidoptera), hama pengisap daun Lawana sp./Sanurus sp. (Flatidae: Homoptera).

\section{SARAN}

Hama terkini yang menyerang tanaman hutan ini perlu terus dimonitor keberadaannya, hal ini agar tidak menjadi masalah dimasa yang akan datang yang dapat menimbulkan kerugian secara materi. Terutama hama yang menyerang bibit seperti trips, karena gejala yang ditimbulkannya mirip dengan serangan penyakit embun tepung. Hama terkini yang menyerang tanaman hutan juga perlu adanya upaya untuk dilakukan penelitian lanjutan agar diketahui teknik pencegahan dan pengendaliannya.

\section{DAFTAR PUSTAKA}

Borror, D.J., Triplehorn, C.A. \& Johnson,N.F. (1992). Pengenalan Pelajaran Serangga Edisi ke-enam. Diterjemahkan oleh Soetiyono Parto Soedjono. Yoyakarta: Gadjah Mada University Press. 
Kementerian Pertanian. (2012). Pengenalan dan pengendalian hama wereng pucuk mete (Sanurus indecora Jacobi) pada tanaman jambu mete. Direktorat Perlindungan Perkebunan, Direktorat Jenderal Perkebunan, Kementrian Pertanian.

Krisnawati, H., Kallio M. \& Kanninen, M. 2011a. Anthocephalus cadamba Miq.: Ekologi, Silvikultur dan Produktivitas. Bogor: CIFOR.

Krisnawati, H., Varis, E., Kallio, M. \& Kanninen, M. 2011b. Paraserianthes falcataria (L.) Nielsen: Ekologi, Silvikultur dan Produktivitas. Bogor: CIFOR.

Morse JG and Hoddle MS. 2006. Invansion biology of thrips. Annual Reviews Entomology. 51: 67-89.

Mound, L.A, \&Kibby, G. (1998). Thysanoptera an identification guide Second Edition. Oxon (UK): CAB International.
Peigler, R.S. (1989). A Revision of Indo Australlian Genus Attacus. The Lepidoptera. California(US): Research Foundation, Inc. Beverly Hills.

Saleh. (2004). Sutera Alam Menunggu Investor. Jakarta: Mitra Bisnis.

Situmorang, J. (1996). An attemp to produce Attacus atlas L., using baringtonia leaves as plant fooder. International Journal Of Wild Silkmoth and Silk 1. $25-29$

Suhardiman. (1996). Kumbang Kelapa (Oryctes rhinoceros L.). Diunduh dari http://www.kumbang-kelapa Oryctesrhinoceros.html. Diakses tanggal 5 Juli 2018.

Susanto. (2005). Pengurangan Populasi Larva Oryctes rhinoceros Pada Sistem Lubang Tanam Besar. Jurnal Penelitian Kelapa Sawit, 14 (1): 2-3.

Susanto. (2012). Pengendalian terpadu Oryctes rhinoceros di perkebunan kelapa sawit. Medan: Mitrakarya. 